\title{
Chemical and Rheological Characteristics of Butter Cake as Affected by Date Seed Powder Addition
}

\author{
Ammar, A. S. **, I. S. Salem**' and R. A. Habiba**** \\ * Food Science Dept. Faculty of Agriculture, Cairo Univ. Egypt \\ ** Nutrition \& Food Science Dept. Faculty of Home Economics, Helwan Univ. Egypt \\ *** Department of Food Industries, Faculty of Agriculture, Suez Canal Univ. Ismailia, Egypt. \\ *Department of Food Science and Human Nutrition, Faculty of Agricultural and Veterinary Sci., Qassim University.
}

Received: $15 / 11 / 2013$

\begin{abstract}
Ground date seeds and wheat flour (72\% extraction) blends (0, 2.5, 5, 7.5, and $10 \%$ date seeds powder) were rheologically evaluated and used to produce butter cake. Results showed that water absorption, batter stability, development time, time to break down, begin of gelatinization, gelatinization temperature and gelatinization maximum were negatively affected by the addition of date seed powder. The processed cake samples were chemically and organoleptically evaluated. Results showed that by increasing date seed powder levels, the fiber, fat and ash contents increased. The substituted cake $(2.5 \%)$ scored high sensory scores and was not significantly $(\mathrm{p}<0.05)$ different from the control. While, the other substituted cakes, $(5,7.5$, and $10 \%)$ scored low sensory scores. Therefore date seed powder could be added to some bakery products such as cakes at a level of $2.5 \%$ of the flour.
\end{abstract}

Keywords: Cake, date seeds, rheology, flour.

\section{INTRODUCTION}

Date (Phoenix dactylifera L.) fruit is composed of a fleshy pericarp and seed. The seed constitutes between 10 and $15 \%$ of date fruit weight (Hussein et al., 1998). The date seed considered a by-product of many date processing plants producing pitted dates, date syrup and date confectionaries (Al-Farsi et al., 2007). At present, seeds are used mainly for animal feeds i.e., the cattle, sheep, camel and poultry industry (Al-Farsi and Lee, 2008). The production of date fruits in the world is estimated at 6.9 million tons, from these approximately 863 thousand tons of date seeds are produced (FAO, 2007). Identifying new ingredients with multiple roles (enhancing the rheological properties of dough and bread quality that are beneficial for health) is one of the priorities of the last decade (Mironeasa et al., 2012). Date seeds could be considered as a great source of valuable products such as phenolics and dietary fibers (Al-Farsi and Lee, 2008), antioxidant activity (Al-Farsi et al., 2007 and Ammar and Habiba, 2010) and oils (Besbes et al., 2004). Many researchers have been studied different composite flours forming mixes in which wheat flour is mixed with chickpea (Faheid and Hegazi, 1991), amaranth (Oszvald et al., 2009), soy and lupin (Doxastakis et al., 2002), pea (Kasprzak and Rzedzicki, 2010), palm date seeds (Bouaziz et al., 2010) and grape seed flour (Mironeasa et al., 2012), therefore, the aim of this study is the evaluation of the chemical and rheological quality of butter cake as affected by date seed powder addition.

\section{MATERIALS AND METHODS}

Wheat flour (72\% extraction), eggs, sucrose, skimmed milk, salt "sodium chloride", baking powder and butter were purchased from local market, Cairo, Egypt. Date seeds were kindly obtained from Al-Saudia For Dates, Qassim, Saudi Arabia.

\section{Preparation of date seed powder:}

The date seeds were ground to a powder using a laboratory mill and the particle size of seeds powder was $0.01 \mathrm{~mm}$. The date seed powder (ground date seed) was kept in closed jars and cooled until used.

\section{Preparation of butter cake:}

Date seed powder was mixed with the wheat flour (72 $\%$ extraction) at $2.5,5.0,7.5$, and $10 \%$. Then, $320 \mathrm{~g}$ of the flour mixture was well mixed for $20 \mathrm{~min}$ with sucrose (175g), skimmed milk (125g), baking powder $(10 \mathrm{~g})$, butter $(125 \mathrm{~g})$, eggs $(120 \mathrm{~g})$ and salt $(2 \mathrm{~g})$. The mixture, with and without (control) date seed powder, were rheologically evaluated and baked at $275^{\circ} \mathrm{C}$ for 30 min. Then, the cakes were allowed to cool and chemically evaluated according to the methods outlined in A.O.A.C. (2000).

\section{Rheological Properties \\ Farinograph measurements}

For 300 gm of wheat flour (control) and wheat flour containing of each 2.5, 5, 7.5, and $10 \%$ ground date seeds were separately studied using Farinograph-E (Brabender GmbH\&Co. KG, Duisburg, Germany), according to standard AACC methods (2000). The parameters determined were percentage of water absorption (WA), batter development time (BDT), batter stability (BS) and time to breakdown (TBD). Wheat flour alone was used as a control.

\section{Amylograph test:}

For $80 \mathrm{gm}$ of wheat flour (control) and wheat flour containing of each 2.5, 5.0, 7.5, and $10 \%$ ground date seeds with $450 \mathrm{ml}$ distilled water were separately studied using Amylograph-E (Brabender GmbH\&Co. KG, Duisburg, Germany) according to standard AACC methods (2000). The parameters determined were begin of gelatinization (BG), gelatinization temperature (GT), and gelatinization maximum (G Max). 


\section{Physical characteristics of cake fortified with date seed powder:}

Physical characteristics such as weight, height and index to volume were determined in butter cake samples containing $0.0,2.5,5.0,7.5$, and $10 \%$ date seed powder.

\section{Sensory evaluation of cake:}

Sensory evaluation of the prepared butter cakes was carried out according to Amerine et al., (1965). Fresh samples of butter cakes containing $0.0,2.5,5.0,7.5$, and $10 \%$ date seed powders were sensory evaluated by 20 panelists. All samples were evaluated for color, texture, taste, odor, appearance and overall acceptability using ten- point hedonic scale, which a score of 10 represented attributes most liked; 5 represented attributes at an unacceptable margin; and 1 represented attributes most disliked.

\section{Statistical analyses:}

The physical and sensory properties data were statistically analyzed using one - way analyses of variance, ANOVA (Rao, and Blane, 1985).

\section{RESULTS AND DISCUSSION}

\section{Chemical composition of date seed powder:}

Proximate analysis of the prepared date seed powder is shown in Table (1). Data show that date seeds contained protein, fat, fiber, ash and total carbohydrate as follows $6,6.6,29.8,1.1$ and $56.5 \%$, respectively. The results indicated that date seed powder contained high amounts of fibers, crude fats and proteins, therefore, date seeds could be used as a source of fibers, fat and protein taking into consideration studying the quality of its fat and protein with respect to their content of essential fatty acids and essential amino acids, respectively. These results are in agreement with those found by Rahman et al., (2007) and Ammar and Habiba (2010).

\section{Butter cake composition as affected by date seed powder addition:}

The butter cake composition of unfortified and fortified cakes with $2.5,5.0,7.5$, and $10 \%$ date seed powder was presented in Table (2). The percentages of ash, moisture, protein, fat, fiber and carbohydrates (control) were $0.73,17.81,7.5,1.3$, and $0.30 \%$, respectively. Increasing date seed powder addition led to increase the content (\%) of fiber, ash ad fat in the fortified cake and decrease the content (\%) of protein. However the rest of constituents were slightly changed.

\section{Effect of added date seed powder on batter rheology properties:}

Changes in rheological properties of the flour are indicative of the quality end use product and also help in understanding the handling proper- ties of dough during processing. Moreover, they may even predict the quality of the bakery products (Sollars and Rubenthaler 1975). The effects of ground date seeds addition $(2.5,5.0,7.5$, and $10 \%$ ) on batter rheology were summarized in Tables (3 and 4). Comparing to control, water absorption was decreased by increasing addition of date seeds powder. This might to be due to the decrease of the gluten content in the dough when wheat flour was substituted by date seed powder. It could be expected that the presence of fibers will increase the water absorption value. But, based on these results, they probably do not completely absorb water during dough mixing but in some later stage, maybe during baking (Nikolic et al., 2011).

Batter stability (BS) is given by time from the Farinograph trace touches the 500 BU line up to the break time. Batter stability decreased when date seed powder was added. Therefore, addition of date seeds powder negatively affected batter stability comparing to the control sample. Also, the time required for batter development or time necessary to reach $500 \mathrm{BU}$ of batter consistency. Dough mixing time values showed that the addition of date seed powder impacted the time the batter maintain its best consistency at the $500 \mathrm{BU}$ line. This may be due to increasing of fiber content. Chen et al., (1988) suggested there is a possible interaction between fiber and gluten that prevents their complete hydration resulting in poor gluten development during mixing. Michniewicz et al., (1991) found increased mixing time of dough with 1-2\% added wheat and rye pentosans, which was attributed to their effects on the aggregation and disaggregation of high molecular weight protein in wheat.

Time to breakdown is shown by the drop of the farinograph curve from the $500 \mathrm{BU}$ line. Batter time to breakdown decreased when date seed powder was added (Fig.1).

Data in Table (4) show that the addition of date seed powder decreased the beginning of gelatinization (transition temperature, BG) comparing to control sample. Moreover, the addition of date seed powder to the flour decreased gelatinization temperature (GT) and gelatinization maximum (G Max) (Fig. 2).

Physical properties of butter cake as affected by date seed powder addition:

The physical properties of unfortified cake and fortified cake with date seed powder addition $(2.5,5.0$, 7.5 , and $10 \%$ ) are presented in Table (5). Weight, height, volume and index to volume in unfortified cake were $863.6 \mathrm{gm}, 5.6 \mathrm{~cm}, 1511 \mathrm{~cm}^{3}$ and $8.66 \mathrm{~cm}$, respectively. Fortification of cake with date seed powder caused a parallel increase in physical properties with increasing the level of ground date seed. However, no statistical difference in index to volume was noticed. Best results, in all physical properties, for the cake were achieved at the fortification level of $2.5 \%$ ground date seeds. In view of the fact that the characteristics of a cake quality are highly dependent on ingredients present in the formulation, chemical characteristics of these ingredients and of their possible interactions (Baik et al., 2000), thus, changes in the amount and type of ingredients can cause changes in quality parameters of the final product (Moscatto et al., 2006).

\section{Sensory evaluation of butter cake as affected by date seed powder addition:}

Table (6) illustrates sensory evaluation scores of fortified cake with date seed powder. The mean scores for color, taste, texture, odor, appearance and overall acceptability of unfortified cake (control) were 8.66, 
$8.8,8.7,8.83$, and 8.73 , respectively. The results of the statistical analysis in this table showed no significant difference between unfortified cake (control sample) and cake fortified with $2.5 \%$ ground date seeds. However, comparing with control, fortification of cake with $5 \%$, and $7.5 \%$ ground date seeds resulted in significant decrease $(\mathrm{P}<0.05)$ in all sensory evaluation parameters. This may be due to changes in the chemical composition, fiber content in particular. Competition for water between date seed fiber and other ingredients in the mix as flour and sugars resulting in a significant factor in the contribution of these ingredients to overall cake flavor in some formulations (Jasberg, et al., 1989).

Table (1): Proximate chemical composition of date seed powder (dry weight basses).

\begin{tabular}{lc}
\hline Components & $\%$ \\
\hline Protein & 6.0 \\
Fat & 6.6 \\
Fiber & 29.8 \\
Ash & 1.1 \\
Total carbohydrates & \\
\hline${ }^{a}$ Cat & 56.5 \\
\hline
\end{tabular}

${ }^{a}$ Carbohydrate calculated by difference.

Table (2): Proximate butter cake composition as affected by date seed powder addition (wet weight bases).

\begin{tabular}{|c|c|c|c|c|c|c|}
\hline Samples & $\operatorname{Ash}(\%)$ & Moisture & Protein & Fat & Fiber & Carbohydrates \\
\hline Control & 0.73 & 17.81 & 7.50 & 1.30 & 0.30 & 72.36 \\
\hline $2.5 \%$ & 0.71 & 14.16 & 7.10 & 1.30 & 0.42 & 76.31 \\
\hline $5 \%$ & 0.94 & 13.34 & 6.50 & 1.40 & 0.61 & 78.11 \\
\hline $7.5 \%$ & 0.65 & 16.51 & 6.30 & 1.45 & 1.01 & 74.08 \\
\hline $10 \%$ & 0.72 & 15.86 & 6.00 & 1.45 & 1.37 & 74.60 \\
\hline
\end{tabular}

Table (3): Effect of added date seed powder on farinograph properties of cake batter.

\begin{tabular}{lcccc}
\hline Flour blends & WA \% & DS (min) & DDT (min) & TBD (min) \\
\hline Control* & 64.3 & 14.1 & 7.3 & 17.1 \\
Control +2.5\% date seeds & 62.0 & 9.6 & 5.4 & 9.6 \\
Control +5\% date seeds & 61.0 & 6.0 & 1.4 & 1.5 \\
Control +7.5\% date seeds & 59.8 & 6.6 & 1.7 & 1.9 \\
Control +10\% date seeds & 58.5 & 9.5 & 1.2 & 1.3 \\
\hline
\end{tabular}

*Control: wheat flour (72\% extraction), WA: water absorption, DS: dough stability, DDT: dough development time, TBD: Time to breakdown.

Table (4): Effect of added date seed powder on amylograph properties of cake batter.

\begin{tabular}{lccc}
\hline Flour blends & BG $\left({ }^{\circ} \mathbf{C}\right)$ & GT $\left({ }^{\circ} \mathbf{C}\right)$ & G Max (AU) \\
\hline Control* & 70.8 & 88.5 & 1001 \\
Control + 2.5\% date seeds & 61.9 & 87.0 & 829 \\
Control +5\% date seeds & 58.8 & 87.1 & 804 \\
Control +7.5\% date seeds & 59.4 & 87.0 & 761 \\
Control +10\% date seeds & 59.4 & 86.9 & 769 \\
\hline
\end{tabular}

*Control: wheat flour (72\% extraction), BG: Begin of gelatinization, GT: Gelatinization temperature,

G Max: Gelatinization maximum.

Table (5): Physical properties of butter cake as affected by date seed powder addition.

\begin{tabular}{|c|c|c|c|c|}
\hline Samples & Weight (gm) & Height (cm) & Volume $\mathrm{cm}^{3}$ & $\begin{array}{c}\text { Index toVolume } \\
(\mathrm{cm})\end{array}$ \\
\hline Control* & $863.6 \pm 13.05^{\mathrm{c}}$ & $5.6 \pm 0.10^{c}$ & $1511 \pm 20^{c}$ & $8.66 \pm 0.73^{\mathrm{a}}$ \\
\hline Control $+2.5 \%$ date seeds & $865.6 \pm 10^{\mathrm{c}}$ & $5.4 \pm 0.90^{\mathrm{d}}$ & $1506.6 \pm 44^{\mathrm{c}}$ & $8.2 \pm 0.10^{\mathrm{a}}$ \\
\hline Control $+5 \%$ date seeds & $858.3 \pm 7.6^{\mathrm{c}}$ & $6.19 \pm 0.10^{\mathrm{b}}$ & $1553.3 \pm 10^{\mathrm{b}}$ & $9.8 \pm 0.98^{\mathrm{a}}$ \\
\hline Control $+7.5 \%$ date seeds & $885.0 \pm 5^{\mathrm{ab}}$ & $5.56 \pm 0.70^{\mathrm{c}}$ & $1566.6 \pm 18^{\mathrm{ab}}$ & $8.46 \pm 1.06^{\mathrm{a}}$ \\
\hline Control $+\mathbf{1 0} \%$ date seeds & $895.0 \pm 5^{\mathrm{a}}$ & $6.53 \pm 0.11^{\mathrm{a}}$ & $1586.6 \pm 2^{\mathrm{a}}$ & $9.16 \pm 0.49^{\mathrm{a}}$ \\
\hline
\end{tabular}

Control: wheat flour ( $72 \%$ extraction). Means followed by different superscripts within columns are significantly different $(\mathrm{P}<0.05)$. 
Table (6): Sensory evaluation of butter cake as affected by date seed powder addition.

\begin{tabular}{lcccccc}
\hline \multicolumn{1}{c}{ Samples } & \multirow{2}{*}{ Color } & Taste & Texture & Odor & Appearance & $\begin{array}{c}\text { Overall } \\
\text { acceptability }\end{array}$ \\
\hline Control $^{*}$ & $8.66 \pm 0.15^{\mathrm{a}}$ & $8.8 \pm 0.10^{\mathrm{a}}$ & $8.7 \pm 0.10^{\mathrm{a}}$ & $8.83 \pm 0.05^{\mathrm{a}}$ & $8.73 \pm 5.76^{\mathrm{a}}$ & $8.63 \pm 0.25^{\mathrm{a}}$ \\
Control $+2.5 \%$ date seeds & $8.40 \pm 9.99^{\mathrm{a}}$ & $8.4 \pm 0.10^{\mathrm{a}}$ & $8.73 \pm 0.15^{\mathrm{a}}$ & $8.32 \pm 0.26^{\mathrm{a}}$ & $8.59 \pm 0.10^{\mathrm{a}}$ & $8.63 \pm 0.15^{\mathrm{a}}$ \\
Control $+5 \%$ date seeds & $5.8 \pm 1.30^{\mathrm{b}}$ & $5.8 \pm 1.12^{\mathrm{b}}$ & $5.67 \pm 1.7^{\mathrm{b}}$ & $5.46 \pm 1.18^{\mathrm{b}}$ & $5.53 \pm 1.15^{\mathrm{b}}$ & $7.93 \pm 0.15^{\mathrm{ab}}$ \\
Control $+7.5 \%$ date seeds & $5.53 \pm 0.15^{\mathrm{b}}$ & $5.6 \pm 0.43^{\mathrm{b}}$ & $5.8 \pm 0.17^{\mathrm{b}}$ & $5.3 \pm 0.99^{\mathrm{b}}$ & $5.53 \pm 0.37^{\mathrm{b}}$ & $7.03 \pm 0.86^{\mathrm{c}}$ \\
Control $+10 \%$ date seeds & $4.3 \pm 9.99^{\mathrm{c}}$ & $3.56 \pm 5.7^{\mathrm{c}}$ & $4.06 \pm 0.05^{\mathrm{c}}$ & $3.62 \pm 0.17^{\mathrm{c}}$ & $3.7 \pm 0.10^{\mathrm{c}}$ & $7.53 \pm 0.32^{\mathrm{bc}}$ \\
\hline
\end{tabular}

*Control: wheat flour (72\% extraction), The average of total score was converted to a descriptive category as follows: Judging scale: very good (9-8), Good (6-7) , Fair (4-5), Poor (2-3) and Very Poor (1). All results are expressed as mean \pm SD

Means followed by different superscripts within columns are significantly different $(\mathrm{P}<0.05)$.

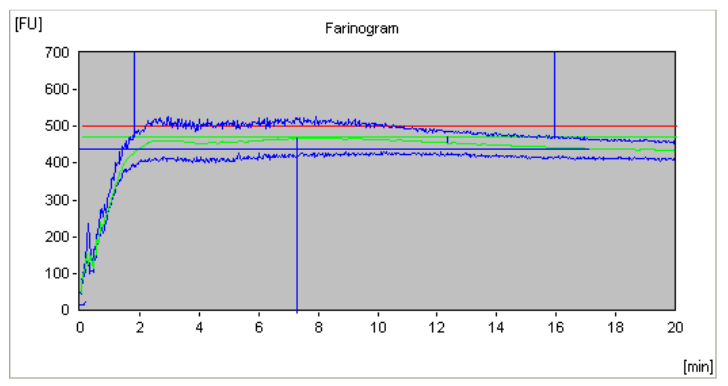

1

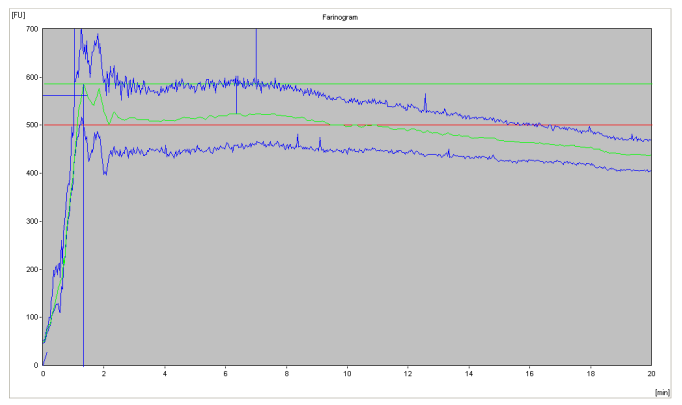

3

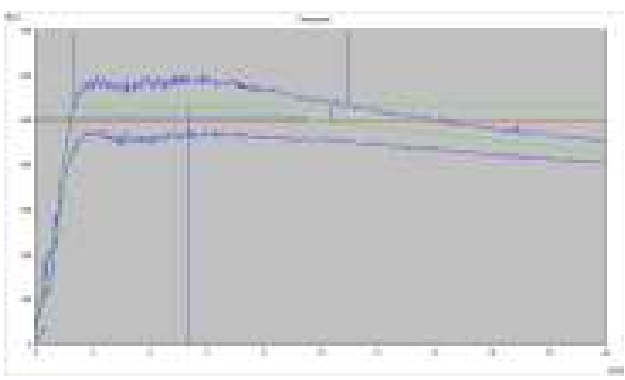

2

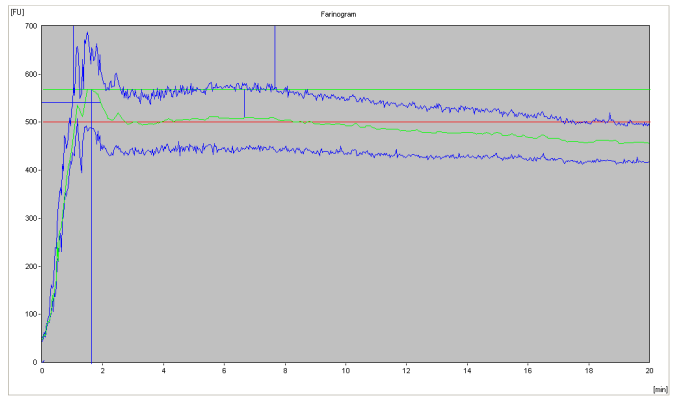

4

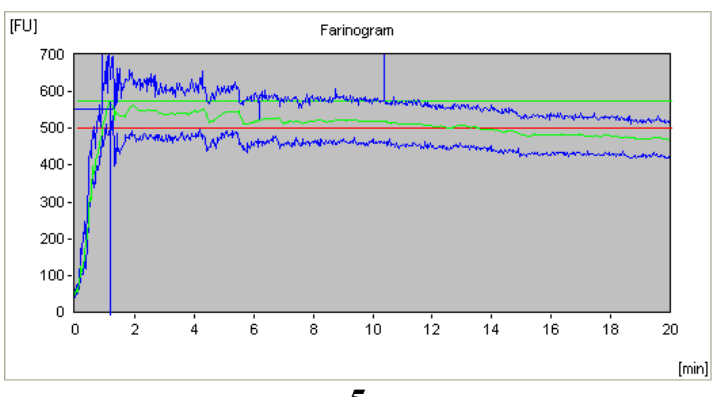

5

Fig. (1): The farinograms of the different blends of wheat flour and date seed powder: 1: control (wheat flour $72 \%$ ), 2: control $+2.5 \%$ date seed powder, 3 : control $+5 \%$ date seed powder, 4 : control $+7.5 \%$ date seed powder, and 5 : control $+10 \%$ date seed powder. 


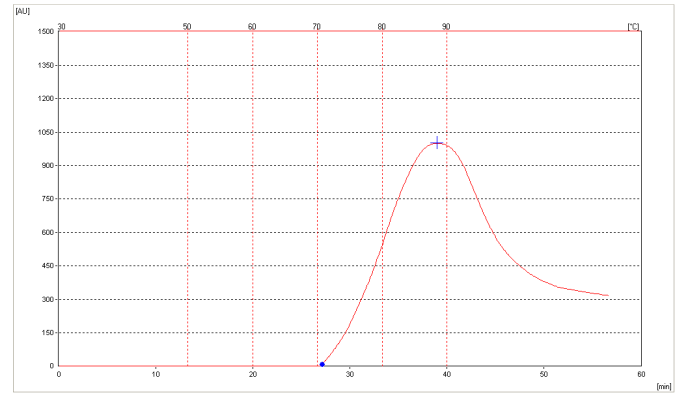

1

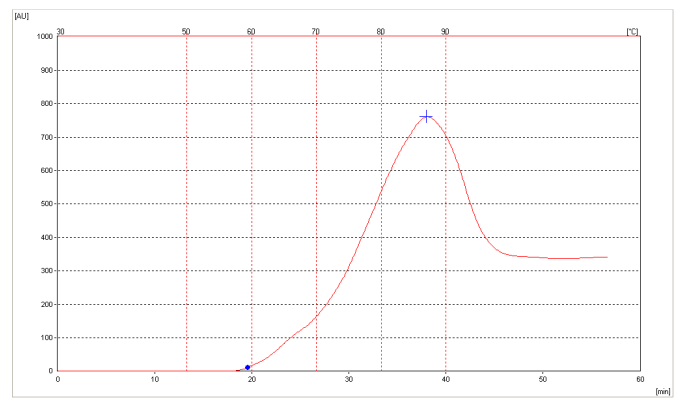

3

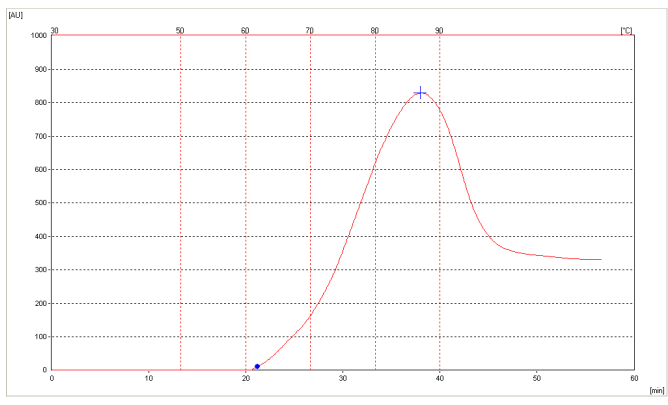

2

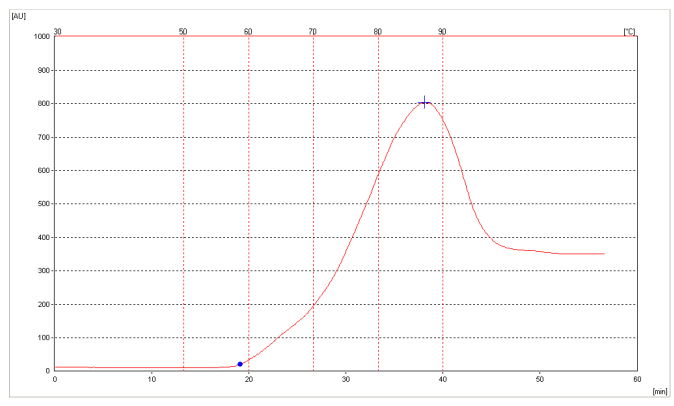

4

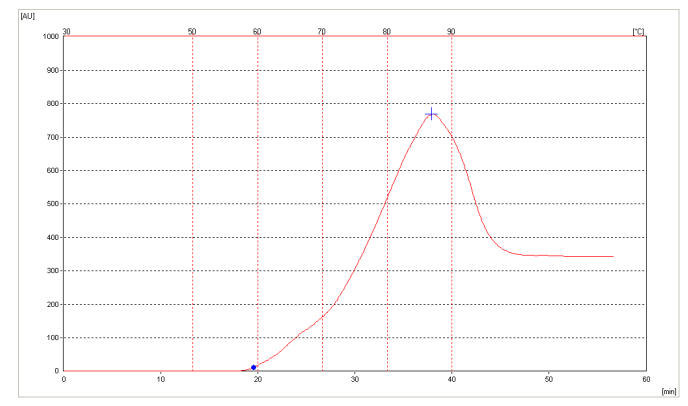

5

Fig. (2). The amylograms of the different blends of wheat flour and date seed powder: 1: control (wheat flour 72\%), 2: control $+2.5 \%$ date seed powder, 3 : control $+5 \%$ date seed powder, 4 : control $+7.5 \%$ date seed powder, and 5 : control $+10 \%$ date seed powder.

\section{CONCLUSION}

From the above results it could be concluded that fortification of the bakery products such as cake with date seed powder at $2.5 \%$ is recommended.

\section{REFERENCES}

A.A.C.C. (2000): Approved methods of the American Association of Cereal Chemists. St. Paul. Minnesota: The American Association of Cereal Chemists Inc.

Al-Farsi, M. A.; Alasalvar, C.; Al-Abid, M.; Al-Shoaily, K.; Al-Amry, M. and Al-Rawahy, F.(2007). Compositional and functional characteristics of dates, syrups, and their by-products. Food Chemistry, Vol.104, 943-947.

Al-Farsi, M. A. and Lee, C. Y. (2008). Optimization of phenolics and dietary fibre extraction from date seeds. Food Chemistry, Vol.108, 977-985.
Amerine, M.; Paglorn, R. and Rossler, E. (1965). Principle of Sensory Evaluation of Foods. Academic Press, New York.

Ammar, A.S. and Habiba, R.A. (2010) Phenolic content and antioxidant activity of date seeds. J. Agric. Veterinary Sciences, Qassim University, 3(1): 310.

AOAC. (2000). The Official Methods of Analysis, Association of Official Analytical Chemists, 17th Ed., Maryland, USA.

Baik, O.D., Marcotte, M. and Castaigne, F. (2000). Cake baking in tunnel type in multi-zone industrial ovens. Part II Evaluation of quality parameters. Food Research International 33: 599607.

Besbes, S.; Blecker, C.; Deroanne, C.; Drira, N. and Attia, H. (2004). Date seeds: chemical composition and characteristic profiles of the lipid fraction. Food Chemistry, Vol.84, 577-584. 
Bouaziz, M.A., Ben Amara, A., Attia, H., Blecker, C. and Besbes, S. (2010). Effect of the addition of defatted date seeds on wheat dough performance and bread quality. J. Texture Studies 41: 511531.

Chen, H., Rubenthaler, G. L., and Schanus, E. G. (1988). Effect of apple fiber and cellulose on the physical properties of wheat flour. J. Food Sci. 53:304-305.

Doxastakis, G., Zafiriadis, I. Irakli, M. Marlani, H. and Tananaki, C. (2002). Lupin, soya and triticale addition to wheat flour doughs and their effect on rheological properties. Food Chem. 77: 219-227.

Faheid, S.M.M. and Hegazi, N.A. (1991). Effect of adding some legume flours on the nutritive values of cookies. Egypt J. Food Sci.19: 147-159.

FAO. (2007). Statistical databases. http://faostat.fao.org Accessed June 2.

Hussein, A.S.; Alhadrami, G.A. and Khalil, Y.H. (1998). The use of dates and date pits in broiler starter and finisher diets. Bioresource Technology, Vol.66, 219-223.

Jasberg, B.K., Gould, JM, and Warner, K. (1989). Higher-fiber, noncaloric flour substitute for baked foods, alkaline peroxide-treated lignocellulose in chocolate cake. Cereal Chem. 66: 209-213.

Kasprzak, M. and Rzedzicki, Z. (2010). Effect of pea seed coat admixture on physical properties and chemical composition of bread. Int. Agrophysics 24: 149-156.

Michniewicz, J., Biliaderis, C. G., and Bushuk, W. (1991). Effect of added pentosans on some physical and technological characteristics of dough and gluten. Cereal Chem. 68:252-258.
Mironeasa, S., Codina, G.G. and Mironeasa, C. (2012). The effects of wheat flour substitution with grape seed flour on the rheological parameters of the dough assessed by mixolab. J. Texture Studies 43: 40-48.

Moscatto, JN, Borsato, D., Bona, E., deOlivera, AS and Hauly, MC (2006). The optimization of the formulation for a chocolate cake containing inulin and yacon meal. International J. Food Sci. Technol. 41: 181-188.

Nikolic, N., Dodic., J., Mitrovic., M., and Lazic., M. (2011). Rheological properties and the energetic value of wheat flour substituted by different shares of white and brown rice flour. Chem. Ind. Chem. Eng. Q. 17 (3) 349-357.

Oszvald, M., Tamas, C., Rakszegi, M., Tomoskozi, S., Bekes, F. and Tamas, L.(2009). Effect of incorporated amaranth albumins on the functional properties of wheat dough. J. Sci. Food Agric. 89:882-889.

Rahman, M.S., Kasapis, S., Al-Kharusi, N.S.Z., AlMarhubi, I.M. and Khan, A.J. (2007). Composition characterisation and thermal transition of date pits powders. J. Food Engineering, 80: 1-10.

Rao, V. N. M. and Blane, K. (1985). PC-STAT, statistical programs for microcomputers. Version 1A. Department of Food Science and Technology, The University of Georgia, Athens, GA, USA.

Sollars, W.F. and Rubenthaler, G.L. (1975). Flour fractions affecting farinographic absorption. Cereal Chem. 52, 420-426.

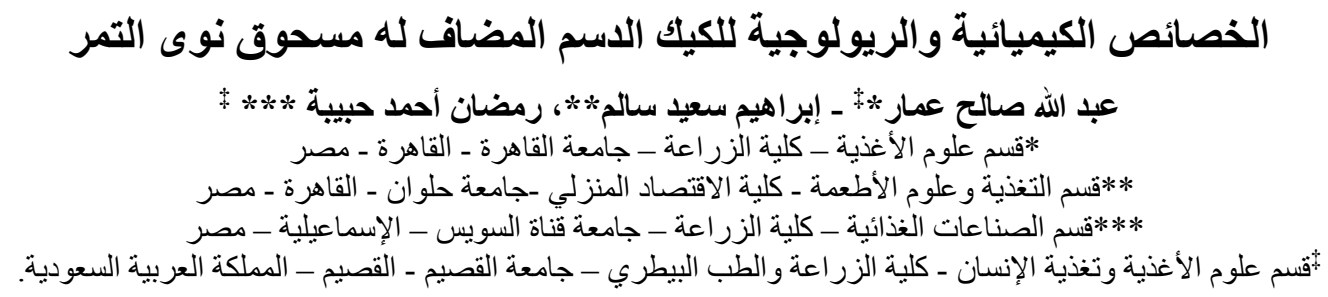

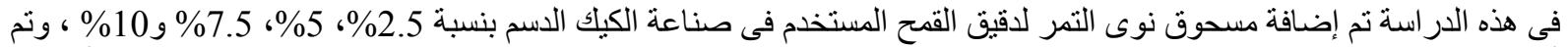

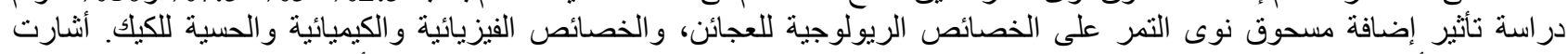

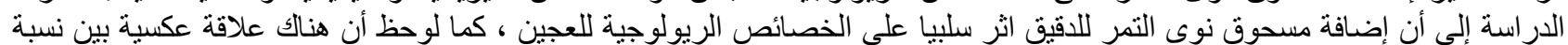

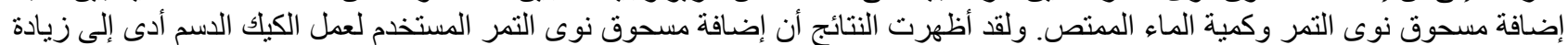

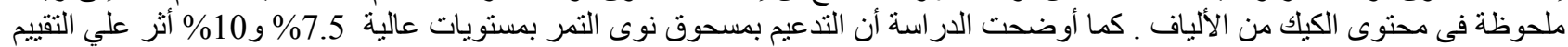

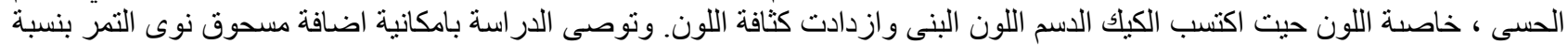
\%2.5 الى بعض منتجات المخابز منل الكيك الدسم. 